\title{
CENTRAL ASIAN GYPSIES: IDENTITIES AND MIGRATIONS
}

\section{ABSTRACT}

During recent years the topic of Gypsy/Roma migration and identities became a burning topic of pan-EUropean public discourse. Much less attention is paid to Gypsy migrations outside the borders of the European Union. The present article has an ambitious goal to fulfill this gap and present contemporary Gypsy migrations in post-Soviet Central Asia, in order to see how this "burning" topic looks outside the European space. After a breakdown of Soviet Union and establishing new independent republics in Central Asia and in connection to economical difficulties, wars and social unrest, in order to make their living, the communities of Central Asian 'Gypsies' revitalised their former nomadic traditions and migrated towards the Russian Federation and within Central Asia also towards Kazakhstan. There they are earning their living through begging and sporadic work in construction and scrap collection.

A central point of this article is to demonstrate the impact of these contemporary migrations on the development of identities and well being of Central Asian 'Gypsies'. The multilevel, hierarchically structured identities of Central-Asian 'Gypsies' are analysed as they appear in different historical contexts as former "Soviet people," member of former ruling class of agricultural proletariat, and as declassed community today; as Central-Asian 'Gypsies' or as citizens of respective Central Asian Republics during migrations in the Russian Federation vis a vis Russian majority society and vis a vis Roma; as well as in the context of the Central Asian region during the migrations to Kazakhstan and in their home countries.

Key words: Central Asia; Gypsies; Lyuli; Mug'at; Roma; migration; identities

ELENA MARIUSHAKOVA-POPOVA,

St Andrews University, Bulgaria, e-mail: studiiromani@geobiz.net

VESELIN POPOV, Institute of Ethnology and Folklore Studies with Ethnographic Museum at Bulgarian Academy of Sciences, Bulgaria.

Correspondence: studiiromani@geobiz.net

This is an Open Access article distributed under the terms of the Creative Commons Attribution 3.0 PL License (creativecommons.org/licenses/by/3.0/pl/), which permits redistribution, commercial and non-commercial, provided that the article is properly cited. (C) The Author(s) 2015.

Publisher: Institute of Slavic Studies PAS [Wydawca: Instytut Slawistyki PAN] 
Streszczenie

W ostatnich latach tematyka migracji i tożsamości Cyganów (Romów) stała się tematem palącym w unijnoeuropejskim dyskursie publicznym. O wiele mniej uwagi poświęca się w nim migracjom Cyganów, które mają miejsce poza granicami Unii Europejskiej. Celem niniejszego artykułu jest wypełnienie tej luki i ukazanie współczesnych migracji Cyganów w posowieckiej Azji Środkowej, po to by móc spojrzeć, jak ów „palący” problem przedstawia się poza obszarem europejskim. Po rozpadzie Związku Sowieckiego i ustanowieniu w Azji Środkowej nowych niepodległych republik, a także wobec trudności gospodarczych, wojen i niepokojów społecznych, w dążeniu do uzyskania środków do życia, wspólnoty "Cyganów” środkowoazjatyckich powróciły do swych dawnych tradycji nomadycznych i migrują na teren Federacji Rosyjskiej jak też w obrębie Azji Środowej do Kazachstanu. Zarabają tu na życie żebraniem, okazjonalnie podejmują pracę na budowach, zajmują się też zbieraniem surowców wtórnych.

Zasadniczą kwestią rozpatrywaną w niniejszym artykule jest ukazanie, jak te współczesne migracje wpływają na budowanie tożsamości i dobrobytu środkowoazjatyckich „Cyganów”. Przedstawiona została analiza wielopoziomowych hierarchicznie ustrukturyzowanych tożsamości "Cyganów" środkowoazjatyckich, przejawiających się w różnych kontekstach historycznych: jako "ludzi sowieckich", członków dawnej klasy przewodniej - wiejskiego proletariatu, i jako zdeklasowanej dziś wspólnoty; jako „Cyganie” środkowoazjatyccy lub jako obywatele odnośnych republik środkowoazjatyckich podczas migracji na terenie Federacji Rosyjskiej vis a vis dominującej wspólnoty społeczeństwa rosyjskiego, jak też vis a vis Romów; a także w kontekście regionu środkowoazjatyckiego podczas migracji do Kazachstanu oraz w ich krajach ojczystych.

Słowa kluczowe: Cyganie; Azja Środkowa; Luli; Mugaci; Romowie; migracje; tożsamość

\footnotetext{
T
} hroughout Central Asia, in the newly independent states (former Soviet republics of Kazakhstan, Kyrgyzstan, Tajikistan, Uzbekistan, and Turkmenistan) live distinctive ethnic communities collectively referred to as 'Central-Asian Gypsies' in English and Tsygane Sredneaziatskie in Russian, the latter term was used in the Russian Empire and the Union of Soviet Socialist Republics (USSR) and is in use also nowadays in the Russian Federation. This appellation connects the Central Asian Gypsies with communities that were called 'Gypsies' in the past. In the last circa 20 years the designation 'Gypsies' is declared pejorative and politically correct term is considered to be 'Roma' which is the self-appellation of a significant part of communities living in Europe. Today we see a mechanical replacement of the previously used designations with the term 'Roma' and the issue of appropriateness or inappropriateness of the politically correct terminology is not on the agenda. Instead of this, on the level of policies we are observing hectic attempts to bring together the different types of communities generally labeled as 'Gypsies' in the past under one umbrella term, and in this way to justify the common policy aims towards them and predetermine common outcomes. There have been numerous attempts, however, by policy makers in the European Union and the Council of Europe level to solve the terminological issue and to find appropriate terminology and an umbrella definition. It is enough to quote the latest (for the time being!) "official" definitions in order to obtain an idea about the lack of relevance to the objectively existing realities and accordingly to the scientific knowledge about these realities. 
The Declaration of the Committee of Ministers on the Rise of Anti-Gypsyism and Racist Violence against Roma in Europe, adopted on 1 February 2012, states:

The term "Roma" used at the Council of Europe refers to Roma, Sinti, Kale and related groups in Europe, including Travellers and the Eastern groups (Dom and Lom), and covers the wide diversity of the groups concerned, including persons who identify themselves as 'Gypsies'. (Declaration, 2012)

This definition is misleading, because on the one hand it put under the cover term 'Roma' not only European 'Gypsies', but even more communities such as Dom and Lom who live outside Europe, while in the same time it directly excludes large groups of people who do not identify themselves as 'Gypsies', but surrounding their population considers them (and refers to them) as to such.

Not better, neither more precise is the definition in the European Framework of National Roma Inclusion Strategies adopted in 2011:

The term "Roma" is used - similarly to other political documents of the European Parliament and the European Council - as an umbrella which includes groups of people who have more or less similar cultural characteristics, such as Sinti, Travellers, Kalé, Gens du voyage, etc. whether sedentary or not (European Commission, 2011)

This definition is misleading too because Roma who live in Central, Eastern and Southeastern Europe share "more or less similar cultural characteristics" with the surrounding majority population much more than with other groups such as Sinti, Kalé, Travellers, Gens du voyage, etc.

In 2012 the European Commission starts the process of implementation of the European Framework of National Roma Inclusion Strategies and provides a new definition:

The term "Roma" is used here, as well as by a number of international organisations and representatives of Roma groups in Europe, to refer to a number of different groups (such as Roma, Sinti, Kale, Gypsies, Romanichels, Boyash, Ashkali, Egyptians, Yenish, Dom, Lom) and also includes Travellers, without denying the specificities and varieties of lifestyles and situations of these groups (European Commission, 2012)

This definition includes even more communities and similarly to the Declaration of the Committee of Ministers on the Rise of Anti-Gypsyism and Racist Violence against Roma in Europe encompasses also Dom and Lom who live outside Europe. It brings no more accuracy in the issue, on the contrary, it only further complicates it.

The recently adopted CAHROM (Ad hoc Committee of experts on Roma issues) definition states:

The terms "Roma and Travellers" are being used at the Council of Europe to encompass the wide diversity of the groups covered by the work of the Council of Europe in this field: on the one hand

a) Roma, Sinti/Manush, Calé, Kaale, Romanichals, Boyash/Rudari;

b) Balkan Egyptians (Egyptians and Ashkali);

c) Eastern groups (Dom, Lom and Abdal); and, on the other hand, groups such as Travellers, Yenish, and the populations designated under the administrative term "Gens du voyage", as well as persons who identify themselves as Gypsies (CAHROM, 2015).

As can be seen, the number of communities included in the term 'Roma' continues, here with added Abdal from Asia Minor.

In these definitions the Central Asian Gypsies are not mentioned explicitly but being designated as 'Gypsies' suppose they should be included too. This was done recently in the definition offered by the United Nations: 
The term "Roma" refers to heterogeneous groups, the members of which live in various countries under different social, economic, cultural and other conditions. The term "Roma" thus does not denote a specific group but rather refers to the multifaceted Roma universe, which is comprised of groups and subgroups that overlap but are united by common historical roots, linguistic communalities and a shared experience of discrimination in relation to majority groups. "Roma" is therefore a multidimensional term that corresponds to the multiple and fluid nature of Roma identity (Report, 2015: 2);

Roma groups are also present in Central Asian countries, where they are known collectively as Lyuli. While those groups are distinct from American and European Roma, they share the experience of exclusion and marginalization from local majority populations (Report, 2015: 3).

Adding the criteria "shared experience of exclusion and marginalization" opens new horizons for expanding the scope of the term 'Roma' and only the future will show how many communities will be covered with this umbrella term in future.

Domination of political discourse over the academic one nowadays is accepted as a norm by the modern academic community, so the term Roma gradually replaced the old designations of communities who previously, all together and equally incorrect, were labeled 'Gypsies'. In the case of 'Central Asian Gypsies', uniting different communities, living in the new, independent states of Central Asia, which mostly have nothing in common both in their origin and in their language, under one umbrella term is absurd too, but even more absurd is to place them under the cover term 'Roma'. The Central Asian Gypsies and the Roma (labeled usually the 'European Gypsies' by their surrounding populations) are perceived as different communities by themselves and by their surrounding population too. And something more, during our field researches in the region (2011-2013) we heard (and have seen) about different cases of mixed marriages among these two communities with representatives of their surrounding population, but have not found a single case (in the past, and nowadays) of a mixed marriage between 'Central Asian Gypsies' and Roma.

Generally speaking, that what unites all the communities called 'Central Asian Gypsies' into one category is their distinction (according to their lifestyle, main occupation, ethno-social structure, certain ethno-cultural characteristics, etc.) and their generally marginal social position throughout the whole Central Asia. However there are also other communities in similar position who are nevertheless not labeled 'Gypsies'. In order to specify about whom is the present article in the first place we should answer the question "Who are the Central-Asian Gypsies?".

\section{MOSAIC OF THE COMMUNITIES IN CENTRAL ASIA DESIGNATED AS 'CENTRAL-ASIAN GYPSIES'}

Within the former USSR the current trend is to use Lyuli as a blanket term for a number of groups known as Central-Asian Gypsies. They are also known as Jughi in Tajikistan, Multoni in some regions of Uzbekistan and sporadically also Gurbath (or Gurvath). They have been present in the land of a contemporary Kazakhstan, Kyrgyzstan, Tajikistan, Uzbekistan and Turkmenistan for centuries, since their ancestors migrated from India (Snesarev, 1960, pp. 24-29; Snesarev \& Troitskaia, 1963, pp. 597-609; Nazarov, 1968b, pp. 43-45, 1968c, 53-55, 1975, pp. 3-23, 1980, pp. 165-185, 1982, pp. 3-28; Demeter, 1980, pp. 143-149; Abashin, 2004; Bessonov, 2008, pp. 27-39; Gabbasov, 2008a; Gabbasov \& Cherenkov, 2008; Khakimov, 2010, pp. 32-53; Marszewski, 2011). 
They are not the only 'Central Asian Gypsies'. There are other, relatively small, groups, mainly in Tajikistan and Uzbekistan, that can be identified as 'intermediate communities'; they often differentiate themselves from Lyuli (and Lyuli likewise differentiate themselves from them) though their surrounding populations perceive them all as a single minority of Lyuli or Central Asian Gypsies. These are the Tavoktarosh (or Kosatarosh, or Sogutarosh in Tajikistan), Mazang and Agha (called also Kashgar Lyuli). The designation 'Mazang' (literally "dark, dark-faced") often leads to confusion, as it can refer to "real" Mazang, i.e. those who use this term to describe themselves as well as to Mug'at, Tavoktarosh, and other 'Lyuli-like communities' (Oransky, 1971b, pp. 202-207). All these groups are relatively close to Lyuli and perhaps in the past were even part of them (Snesarev, 1960, pp. 24-29; Snesarev \& Troitskaia, 1963, pp. 597-609; Nazarov, 1968b, pp. 43-45, 1975, pp. 3-23, 1980, pp. 165-185, 1982, pp. 3-28; Demeter, 1980, pp. 143-149; Bessonov, 2008, pp. 27-39; Gabbasov, 2008b; Khakimov, 2010, pp. 32-53).

The region is also home to a number of other groups usually defined by scholars as 'Gypsy-like communities' such as the Chistoni, Kavol, Baluj and Parya. Relative newcomers to the region (their ancestors migrated here from Afghanistan and India in $18^{\text {th }}-19^{\text {th }}$ centuries), they are more obviously distinct from the Lyuli. All of these groups maintain their differentiation (including the practice of endogamy) and may even strongly oppose being classed under the Lyuli heading (Oransky, 1961, pp. 62-77, 1964a, pp. 3-16, 1964b, pp. 62-75, 1971a, pp. 66-99, 1977, 1983; Nazarov, 1968b, pp. 43-45, 1975, pp. 3-23, 1982, pp. 3-28; Demeter, 1980, pp. 143-149; Abashin, 2004; Bessonov, 2008, pp. 27-39; Gabbasov \& Cherenkov, 2008; Khakimov, 2010, pp. 32-53).

The division of the so-called Lyuli and other 'Gypsy-like communities' in Central Asia can be presented schematically as follows:

\begin{tabular}{|c|c|c|c|c|}
\hline Central Asian 'Gypsies' & \multicolumn{4}{|c|}{ Lyuli / Jughi / Multoni / Ghurbat / Ghorbat } \\
\hline $\begin{array}{l}\text { Intermediate } \\
\text { Communities }\end{array}$ & \multicolumn{2}{|c|}{$\begin{array}{c}\text { Tavoktarosh / } \\
\text { Kosatarosh / Sogutarosh }\end{array}$} & Mazang & $\begin{array}{c}\text { Agha / } \\
\text { Kashgar Lyuli }\end{array}$ \\
\hline 'Gypsy-like' Communities & Chistoni & Kavol & Baluj & Parya \\
\hline
\end{tabular}

The Lyuli call themselves Mug'at, from an Arabic term meaning "fire cult followers" or "heathen" applied in the past to Zoroastrians; it has persisted despite the fact that they have been Sunni Muslims for centuries. They are subdivided by the geographical regions with which they are historically associated, e.g. Samarkandikho, Karshigikho, Mug'atoi bukhorgi, etc., and into patronymic clans (tupar) which are in turn comprised of separate extended families (avdo) (Nazarov, 1968a, pp. 43-45, 1975, pp. 3-23, 1983, pp. 3-38; Abashin, 2004; Bessonov, 2008, pp. 27-39; Gabbasov \& Cherenkov, 2008).

Beyond the borders of the former USSR, small groups descended from Mug'at who migrated in the late nineteenth and early twentieth century from what was then Russian Turkestan are to be found in Afghanistan, where they are called Ghorbat. They continue to use self-appellations such as Kulobi, Bukhori, Samarkandi, etc. (Günther, 2007, pp. 103-120, 2011, pp. 86-98). The latter two obviously derive from Bukhara and Samarkand, suggesting that these regional names persist even after moving away. 
The Mug'at, a hierarchically structured community most commonly known as Lyuli by neighboring populations, have for centuries been an integral part of Central Asian life. They live primarily in Uzbekistan and Tajikistan, with smaller populations in Kazakhstan and Kyrgyzstan (mainly in the Fergana Valley) as well as a small presence in Turkmenistan. They inhabit both major urban centers such as Samarkand, Bukhara and Tashkent, and rural areas (Snesarev, 1960, pp. 24-29; Snesarev \& Troitskaya, 1963, pp. 597-609; Nazarov, 1968a, pp. 43-45, 1975, pp. 3-23, 1980, pp. 165-185, 1983: pp. 3-38; Bessonov, 2008, pp. 27-39; Gabbasov \& Cherenkov, 2008; Khakimov, 2010, pp. 32-53).

They are generally multilingual, commonly having a mastery of both Uzbek (even outside of Uzbekistan proper) and often also Russian, which retains a legal status of "language of transnational communication" throughout most countries of Central Asia. All our communication with Lyuli men, women and even children was conducted in Russian, and none of them had any significant difficulties operating in it. Their mother tongue, however, is Tajik. They often also possess Tajik preferred identity, and especially outside of Tajikistan tend to publicly identify as Tajiks in addition to or in place of their own ethnic identity (Snesarev, 1960, pp. 24-29; Oransky, 1961, pp. 62-77, 1964a, pp. 62-75, 1964b, pp. 3-16; 1971a, pp. 66-99; 1977; 1983; Snesarev \& Troitskaya, 1963, pp. 597-609; Khakimov, 2010, pp. 54-60).

Due both to the complex nature of their identity and because it is often perceived negatively by others, many Lyuli self-declare their "nationality" (natsional'nost' in Russian; term used in Soviet times and in use also in post-Soviet space for ethnic belonging and self-identification) as Tajik rather than Tsygane ("Gypsies") on census forms during the Soviet period. As a result, official data are not a reliable indicator of the true size of the population. Bearing this in mind, official figures are as follows:

- In 1926 3,710 persons in the Uzbek SSR (which then included today's Tajikistan) declared themselves as Tsygane;

- In 1939 the figures were 5,487 in the Uzbek SSR, 1,193 in the Tajik SSR, 4,257 in the Kazakh SSR, 644 in the Kyrgyz SSR and 190 in the Turkmen SSR;

- The 1959 figures were 7,860 in the Uzbek SSR, 1,556 in the Tajik SSR, 7,265 in the Kazakh SSR, 776 in the Kyrgyz SSR, and 103 in the Turkmen SSR;

- In 1970 the number of self-declared Tsygane was 11,371 in the Uzbek SSR, 1,171 in the Tajik SSR, 7,766 in the Kazakh SSR, 863 in the Kyrgyz SSR, and 218 in the Turkmen SSR;

- The 1979 figures for the Uzbek SSR were 12,581; in the Tajik SSR 1,139; in the Kazakh SSR 8,626; in the Kyrgyz SSR 1,927, and in the Turkmen SSR 357 persons;

- In 1989 in the Uzbek SSR 16,397 persons declared themselves Tsygane; in the Tajik SSR 1,791 persons; in the Kazakh SSR 7,165 persons; in the Kyrgyz SSR 990 persons, and in the Turkmen SSR 119 persons (Perepisi naseleniia, 2012).

The Newly Independent States that have emerged in the region since the collapse of the USSR have not conducted censuses on a regular basis, so available data are incomplete, fragmented and in many cases approximate. So for example, according to expert estimates formulated in 2000 there were only about 5,000 Tsygane (Roma and Lyuli) in Uzbekistan; that same year, 4,300 individuals self-declared as Tsygane in the census of the Republic of Tajikistan. (Tul'sky, 2005) To put these figures in context, there was significant emigration, particularly of ethnic Russians and Roma, from Central Asia during 
this period. The comparison of data shows that some States (Uzbekistan in particular) experienced a dramatic decrease in the Lyuli population, while others, like Tajikistan, experienced significant increases.

Both trends are associated with changes in public attitudes towards this population: the more negative and stigmatizing the public perception of Tsygane or "Gypsies", the more likely Lyuli are to hide their identity. In any case, the actual number of Lyuli currently living in the countries of Central Asia is significantly higher than the official figures, just as it was in previous historical periods.

The Lyuli traditionally lived a nomadic or semi-nomadic life style, stopping for the winter months in rented houses or agricultural outbuildings in the kishlaks (from the Turkic, a rural settlement in Central Asia). Men's characteristic occupations included trading horses and donkeys, producing various objects from horsehair, making costume jewelry, itinerant trading, providing cures for the ailments of humans and/or animals, seasonal agricultural labor, providing music for various family and village celebrations and woodworking. From producing different wooden utensils derive even some group's self -appellations, e.g. Tavoktarosh from tavok (wooden dish), Sogutarosh from sugu (wooden bowl), Kosatarosh from kosa (wooden cup), Koshuktarosh from koshuk (spoon), etc. (Khakimov, 2010, p. 39) Women helped their husbands in these activities but their main occupation was simply begging, combined in many cases with fortunetelling and other magical and folk-healing practices (Nazarov, 1975, pp. 3-23, 1980, pp. 165-185, 1982, pp. 3-28; Abashin, 2004; Bessonov, 2008, pp. 27-39; Gabbasov \& Cherenkov, 2008; Khakimov, 2010, pp. 69-78).

After the October Revolution of 1917, the new Soviet government implemented policies designed to transform the socio-economic situation of so-called Tsygane Sredneaziatskie ("Central Asian Gypsies"), the main objectives of which were forced settlement and inclusion in the State-run labor force (a policy pursued by other communist regimes in Central and Eastern Europe as well). Because the Lyuli were classed as Tsygane Sredneaziatskie ("Central Asian Gypsies"), i.e. a part of the Tsygane minority, they were subject to all measures undertaken by the Soviet State with regard to Tsygane. In the 1920s a number of Tsyganskie kolkhozy ("Gypsy collective farms") and Tsyganskie arteli ("Gypsy cooperatives") were set up throughout the Soviet Union. Tsyganskie kolkhozy in Central Asia engaged mainly in the cultivation of cotton (by 1937 there were thirteen such in Uzbekistan alone) while the region's Tsyganskie arteli were mainly involved in the collection of scrap metal and other secondary raw materials, wood processing, basket making, etc. Tsyganskie shkoly ("Gypsy schools") and, in the case of Central Asia, separate Tsyganskie klassy ("Gypsy classes") were established as well.

In 1938, however, State policy towards nationalities, including Tsygane, underwent radical reform, shifting from the "special policy" of supporting ethnic development towards what would today be termed "mainstreaming": "Gypsy" schools and classes were closed and the pupils moved into mainstream education; "Gypsy"-specific collective farms and cooperatives were dissolved, and those engaged in them redirected towards existing collective farms in rural areas and towards factories and enterprises in the towns ( $\mathrm{Na}-$ zarov, pp. 1968c: 67-73, 1969b, pp. 73-77, 1970; Bessonov, 2008, pp. 27-39; Gabbasov \& Cherenkov 2008).

On the fifth of October 1956 this policy was given increased impetus by Decree No. 1373 of the Presidium of the Supreme Soviet of the USSR On the Admission to Labor of the Gypsy Vagrants, followed by Ordinance No. 685 of the Council of Ministers of 
the USSR on the twentieth of October the same year. The latter prohibited the nomadic way of life and criminalized those who would try to avoid sedentarization, simultaneously obliging local authorities to assist those affected by offering them housing, employment and schooling. (Polnoe sobranie zakonodatel'stva SSSR, n.d.) As a result, Tsygane (including $L y u l i)$ gradually adopted an almost entirely sedentary lifestyle and became an integral part of the social structures of Soviet society, though generally at its periphery. Nominally they became part of the 'new historical, social and international unity of people', the 'Soviet people'. Soviet people as political concept was adopted at 70 s of 20th century and was determined as: "A new historical, social, and international community of people having a common territory, economy, and socialist content; a culture that reflected the particularities of multiple nationalities; a federal state; and a common ultimate goal: the construction of communism (Bol'shaia Sovetskaia Ėntsiklopediia, 1970-1978). In terms of marxist-leninist class ideology the Lyuli were part of the ruling class, as the so-called "agricultural proletariat". Some individuals went on to higher education, including university degrees, and achieved decent social positions. The most famous representative of this new Lyuli elite was Professor Khol Nazarov (Demeter, Bessonov, \& Kutenkov, 2000, pp. 240-242; Marushiakova \& Popov, 2003, pp. 293-294, 2008).

Following the 1991 breakup of the USSR and the establishment of independent States in Central Asia, the relatively high degree of social integration enjoyed by the Lyuli during the Soviet era proved unstable and superficial. In the ensuing conditions of severe economic crisis and exacerbated social relations, the majority of Lyuli lost their jobs and were left with literally no means of subsistence. The ensuing social climate exacerbated ethnic tensions, reviving and intensifying negative attitudes formulated over the centuries, transformed them to declassed community (phenomena also experienced by the Roma populations in the former communist block of Central and Eastern Europe). Simultaneously, as newly independent Central Asian countries have engaged in intensive "nation building," the Lyuli find themselves pushed from the so-called "titular nation" (titul'naya natsia a Russian term used in the region to designate a given country's dominant population) and in most countries of the region are once again being perceived as "aliens".

A bad economic situation, armed conflicts, negative attitudes towards them and worsening interethnic relations are, in combination with the generally low level of education among the Lyuli, the main factors behind the rapid deterioration in their overall circumstances. The situation continues unabated and, to date, there have been no significant efforts to improve it, whether through domestic mechanisms or foreign aid. The Lyuli have not been included in any of the national or international action and support programs directed towards Europe's Roma and Sinti, nor has their case been espoused by any social movement or NGO. The only exception we come across is the "Community Foundation of Central Asian Gypsies in the Osh region 'Luli'", established by non-Lyuli in 2002 in Kyrgyzstan. The Foundation however failed to implement any projects.

\section{LYULI IN THE RUSSIAN FEDERATION}

Lyuli migration (especially from Uzbekistan and Tajikistan) increased significantly in the aftermath of the collapse of the USSR. Most of the region's Newly Independent States have, since their emergence, been in severe social and economic crisis, which became 
a major push factor for the first Lyuli migration. The breakdown of public and municipal services and the collapse of many enterprises, particularly collective farms, coupled with deteriorating public attitudes towards them, left a huge proportion of Lyuli permanently unemployed with no means of subsistence and no prospect of regular work. As an additional "push" factor, from 1992-1997 Tajikistan was in a state of outright civil war.

Changes in the legislation of the Russian Federation facilitated migration. In 1991 Chapter 209 of the Criminal Code, under which so-called tuneyadstvo (social parasitism or the maintenance of a parasitic lifestyle - in a word, begging) was subject to prosecution, was repealed. The above mentioned chapter was inherited from the time of the USSR and reflected Soviet thinking, in which unemployment was ideologically unacceptable and incompatible with a "socialist way of life". It was therefore officially eliminated and those who were not engaged in either work or study were subject to prosecution. Begging, considered a form of "social parasitism", was a criminal offense. Repeal of this chapter was indication of a significant change in policies of Russian Federation, which influences change in living strategies of Lyuli.

Large scale Lyuli migration directed towards the Russian Federation and other independent countries forming on the ruins of the former USSR began in the early 1990s and continues to the present day. It remains a major source of their livelihood. Lyuli migrate as whole families, men, women and children, including infants. The women's main occupation is begging (usually with small children) on the streets of big cities (particularly Moscow and St. Petersburg), a highly visible activity that attracts negative attention from Russian society and media. The Lyuli travel mainly by train. Their principal point of entry into the Russian Federation is the town of Astrakhan due to its direct rail connections with Uzbekistan (Bukhara and Samarkand) and Tajikistan (Dushanbe), and also because, as most of our Moscow-based informants emphasized, "the people there are better towards us". Their second major entry point is Novosibirsk, with rail links to the Fergana Valley and Tashkent regions of Uzbekistan. Other entrance points are cities such as Saratov, Samara, Chelyabinsk, Yekaterinburg and Omsk: the rail network enables Lyuli to move not only to the European part of the Russian Federation but to Siberia and the Far East as well.

Lyuli migration is impressive in both scale and scope. Although primarily directed towards the largest cities, Moscow and St. Petersburg, Lyuli are to be found on the streets of almost all of the Russian Federation's major urban centers, including Arkhangelsk and Murmansk on the shores of the Arctic Ocean in the extreme northwest and Vladivostok on the Pacific coast in the Far East. Generally they prefer larger and more developed economic centers, but have also made their way to more remote and less developed regions. Thus, for example, the first Lyuli appeared in Syktikvar (in the Komi Republic) as early as in 1993; their arrivals and departures, and the legality of their remaining, are still periodically reported and discussed in local media. ("Vremia liuli: Tadzhikskie tsygane izvlekaiut pol'zu iz nesovershenstva rossiĭskikh zakonov", 2003) In 2002 some 315 Uzbek Lyuli were expelled from Surgut in Khanty-Mansi Autonomous Region in western Siberia. ("Surgut "zachistili" ot uzbekskikh tsygan", 2002) In 2008 the local authorities and residents of Yuzhno Sakhalinsk (on Sakhalin Island, just north of Japan) held public discussions ("Na Sakhalin na zarobotki vpervye pribyla gruppa tsygan iz blizhnego zarubezh'ia", n.d.; "Muzhchiny iz tsyganskogo tabora pytaiutsia naĭti rabotu v Yuzhno-Sakhalinske", 2008) to consider the still unresolved issue of how to expel Central Asian Lyuli ("K nam priekhal tabor", 2010). 
The Lyuli quest for new economic spaces went beyond the boundaries of the Russian Federation. In the 1990s they were relatively common on the streets of the major cities of the Ukraine. In Belarus they began to arrive in significant numbers in the early 1990s; by 1997 they had established a major camp on the outskirts of Minsk, and they were eventually deported by arrangement with the Embassy of Tajikistan. ("Neprikayannye", 1997)

Tightening border controls have curtailed and gradually redirected Lyuli migration, which is now by and large confined to the States of Central Asia and the Russian Federation. In recent years Kazakhstan has attracted more and more migrant workers, among them Lyuli, from neighboring countries, especially Uzbekistan and Kyrgyzstan. Lyuli migrants in Kazakhstan typically combine begging with seasonal agricultural labor, those from Uzbekistan are mainly involved in the harvesting of cotton while Lyuli from Kyrgyzstan generally work with tobacco.

In their migrations Lyuli have for years used their old Soviet passports for entering the Russian Federation, and the adoption of the Federal Law on Citizenship of the Russian Federation in 2002 did not change the situation. As citizens of their countries of origin (primarily Uzbekistan and Tajikistan) which are part of the Commonwealth of Independent States, Lyuli are entitled to visa-free entry to the Russian Federation and to remain there for a period of up to three months. They are, however, required to register domicile within three days of arriving in the country. Few do so, preferring to set up temporary camps or shantytowns on the outskirts of population centers.

Lyuli in the Russian Federation face both old and new problems and difficulties arising from their migrant status. The most common of these has always been the threat of deportation on grounds of failure to register or overstaying the three-month deadline. It should be noted that although. These legal requirements are violated by the majority of migrant workers deportations are rare, except in the case of Lyuli-a real possibility if they fail to pay the blackmail often demanded by the police. They also have frequent dealings with inspectors from the migration services. Eviction and/or deportation may be carried out on grounds of lack of proper residence or work permits, illegal accommodation, suspicion of spreading infectious disease, complaints from citizens, public nuisance (usually a euphemism for begging, especially with small children) etc. Local mafia types, attracted by myths of hereditary gold and high earnings from begging and supposed drug dealing, are yet another threat. In the same time we also heard stories from colleagues working with Lyuli communities in Russia about mafia members who went to Lyuli camps with the intention of extorting money from them but, shocked by their extreme poverty, gave them small donations instead.

In April 2012 employees of the Federal Migration Service in the Novosibirsk area discovered an illegal tent settlement in the forest not far from the city of Berdsk. It was home to Lyuli from Uzbekistan who worked the city's litter bins and dumps, collecting cans, plastic bags, bottles, etc. which they sold on to scrap merchants, earning on average 100-150 rubles (between €2.50 and €4) per family per day. Law enforcement agents detained thirty citizens of Uzbekistan. First offenders without migrant registration were fined, while repeat violators were deported by court order ("V Berdske obnaruzhili lyuli", 2012).

In July 2012, in the same region, people with holiday homes in the countryside near Novosibirsk notified local agents of the Ministry of Internal Affairs of the Russian Federation and of the Office of the Federal Migration Service about the existence of an illegal tent settlement. Forty-six Uzbek Lyuli were found to be living there. They had arrived 
the previous month and their main occupation was collecting scrap metal from landfills ("Nelegal'nyı tsyganskiĭ tabor byl obnaruzhen pod Novosibirskom", 2012). Fourteen of them were found to be in the territory of the Russian Federation in violation of legal requirements, and were deported.

Some of our Lyuli informants claim that such actions are often more a case of forcing people out of a given region than of bona fide deportation. One such case occurred in the Siberian city of Tyumen in 2010. Lyuli living there were found to be carrying a number of infectious diseases such as scarlet fever and polio. The local authorities gathered them, gave them two train carloads to load their belongings, and drove them outside the borders of the Tyumen administrative region.

In other cases, Lyuli have learned to exploit the authorities' willingness to get rid of them. For example in April 2012, in the Chelyabinsk region, ten Lyuli adults, including a mother with five children, voluntarily presented themselves at the local bailiff's office, from which they were taken directly to Balandino airport and repatriated. They had been living in a tabor (temporary camp) on the outskirts of Chelyabinsk, between the Meridian Highway and the railroad tracks. Their incomes, mostly from begging on the streets, were low, so they chose to return home at public expense. After a few months back in Tajikistan, one of the families headed back to Russia, this time to Moscow.

Years of constant migration have enabled the Lyuli to gather significant amounts of practical information about conditions in different regions of Russia, which in turn allows them to plan and direct their migrations. For example, during major Orthodox holidays, when believers are inclined to give alms, they head to the most visited churches and monasteries, while during Muslim holidays they turn to regions with a predominantly Muslim population. In Dagestan, for example, the Lyuli are mostly known as "Tajiks", i.e. they are not generally regarded as "Gypsies". They arrive annually in the capital Makhachkala around the time of the Bayram festival and can be found begging at all road intersections. Typically, they rent cheap houses in the suburbs, with large numbers of people sharing dwellings, for the duration of their stay. When the holidays are over, they leave the country.

In some places a gradual transition from illegal camps and temporary shantytowns to permanent residence in the towns has been made. In downtown Kazan, for example, a whole Central Asian quarter has taken shape since the 1990s. Its old, sometimes formerly abandoned, houses are mostly inhabited by Lyuli, who make a living by begging in the major markets and sometimes selling dried fruit ("Ėkspert: V tsentre Kazani liuli zakhvatili tselyı̆ kvartal", 2012).

Lyuli migrants have relatively limited possibilities for economic activity. In the early 1990s, when large scale Lyuli migration was a new phenomenon, they usually traveled to the Russian Federation in spring and stayed there until returning to their homelands for the autumn harvests. From very early on, however, some were already overwintering abroad, in camps (e.g. in the forests near Moscow) or abandoned buildings, surviving mainly by begging. In the early years, these families relied almost exclusively on the earnings of women and children, whose main occupation is begging on the streets of big cities and in front of churches and/or mosques. It is only within the past four to five years that men have also become significant contributors to the family economy. Typically, they are employed (sometimes legally, but more often illegally) in temporary construction jobs or other unskilled labor, or involved in collecting scrap and other secondary raw materials.

In recent years more and more Lyuli (especially men) are seeking to regularize both their residential and their employment status. In some rare cases Lyuli women - for 
example those working at fruit and vegetable warehouses near Moscow - have also found employment in the mainstream economy. The general trend is towards long-term stays in the Russian Federation, with an accompanying increase in efforts towards legalizing residence and employment, and some even seeking Russian citizenship. Naturally, the longer Lyuli have been in Russia, the more experience they gain, and the easier it becomes for them. They cease to dress in ways that distinguish them from the surrounding population, declare themselves to be Tajiks, and find legal or semi-legal low-skill jobs in construction, scrap collection, sanitation, trade and communal services, and so on.

Although they are to be found throughout the vast territories of the Russian Federation, Moscow remains the preferred destination for Lyuli migrants (especially from Tajikistan and Uzbekistan) as well as for other migrants from Central Asia. They live in camps, rented buildings, abandoned houses, barns and sheds as well as basements and residential buildings, a dozen people together, and even on building sites (so they don't need to travel to work). They are mainly employed in construction and as janitors (the preferred job, as it includes accommodation). During our field research in Moscow in the autumn of 2012, the only Lyuli remaining in the city were those with jobs in construction or as janitors, while those who lived in camps had journeyed back to their homelands because of cold weather.

Throughout the Russian Federation, all schools are required to accept the children of migrants whether they are legal or not, but in practice only a limited number of schools in Moscow do so. However not one of the Lyuli we interviewed in Moscow had enrolled their children in school there. A significant obstacle to Lyuli children's school enrolment is the practice of giving birth outside hospital, as a result of which they have no birth certificate or other ID. In 2006 the St. Petersburg Center for the Prevention of Child Neglect and Drug Addiction investigating an illegal Lyuli camp near the city discovered fifty children without any personal documents (ADTs Memorial, 2010, p. 43).

The narratives of our Lyuli informants in Moscow and nearby satellite towns focused primarily on issues of migration and their life in the Russian capital. Most had accumulated relatively long experience of this type of labor migration, and many recalled the 1990s when they first set up camps in local woodlands. The following story told us by two Lyuli women from Tajikistan, in Moscow in autumn 2012 describes the situation:

We would choose a camping place that couldn't easily be seen, but was relatively close to an elektrichka [electric train] station so we could get in to Moscow. We made tents, kept the camp clean, and we had an aksakal with us for solving problems. But it was a hard time - the women and children went begging every day and sometimes people came and collected money in return for letting us stay there. Some people still live like that, but now we have shelter and work, and we're earning more money, so life is much better. As for how it will be in future ... who knows?

Most of the Lyuli we interviewed indicated gradual but steady improvement in their situation. Ten to fifteen years ago camp dwellers lived under double pressure from both criminal elements and the police, both of which had to be bribed, and under constant threat of deportation or expulsion from the Moscow region. Their main income came from the not particularly profitable occupation of begging, carried out by women and children. Work for men (usually illegal, in construction) was hard to find.

In the last five to ten years the Russian State, and particularly the greater Moscow region, has experienced rapid economic growth and achieved greater stability. These developments have dramatically transformed the lives of Lyuli migrants. Our informants highlig- 
hted this in every conversation, emphasizing positive changes on the first place in relation to accommodation - from forest camps to urban or village conditions. So one Lyuli man from Tajikistan told us in Moscow in autumn 2011: "Don't believe in the romance of the nomadic life. Of course it is much better to live in house than a tent in the forest!" The positive changes are seen also in the nature of basic work activities within their large families, from subsistence on the begging of women and children the move is toward more or less regular employment for men as janitors, drivers, or construction workers.

Increased income, improved living conditions and partial legalization have made possible the gradual formation of stable networks among Lyuli migrants based on kinship/ clan and region of origin. These are intertwined with, but separate from, the general networks of migrant workers from Central Asia, and community life takes place largely within these frameworks. There is no trend towards a return to their homelands, at least among those we interviewed, who almost unanimously expressed the opinion that "Things are not getting better at home, and there is no hope that this will change soon".

Attitudes within Russian society towards Lyuli migrants are ambivalent. In the early years of their migrations, Lyuli were not clearly identifiable as such. The media usually referred to them as Tajiks or as Roma (local European "Gypsies"). In this context they were often accused of drug trafficking and other criminal activities popularly associated with these groups. As a result they became victims of cruel racist and nationalistic attacks, including the burning out of some temporary camps, e.g. in the woods near the St. Petersburg suburb of Gorelovo in 2009 (Shkurenok, 2009). In human rights circles the pogrom of a Lyuli camp near St. Petersburg in 2003, in which skinheads killed six-year-old Nilufar Sangoeva, was a particularly well known case (ADTs Memorial, 2005, pp. 132-133). After lengthy court proceedings the perpetrators received heavy penalties.

Over the last few years the public visibility of Central Asian Lyuli in Moscow has decreased somewhat, with less women and children begging on the streets and in front of churches. Begging continues, but has shifted both in where it is done and when. Nowadays it is concentrated in monasteries and mosques on religious holidays and in markets (especially food markets). It is accompanied with magical services. Early in the morning Lyuli women burn incense on the market stalls of their compatriots from Central Asia, using special herbs (called isryk or adraspan) which according to Central Asian beliefs serve as ritual purification, dispel evil forces and attract luck and prosperity.

Over the course of time Muscovites have become more and more aware of "Tajiks" (the term used nowadays to describe all migrant workers from Central Asia, regardless of ethnic background and country of origin). Ethnic tensions are steadily growing and fear of criminal activities by "persons of Caucasian nationality" is gradually being replaced by fear of a mass invasion by "Tajiks" who "have already occupied Moscow", which "no longer looks like a Russian city."

The exact number of migrants from Central Asia, be it in Moscow in particular or the Russian Federation as a whole, is extremely difficult to determine. Lack of precision around the concepts of legal or illegal "migrant workers" is compounded by their constant movement between Russia and their homelands. According some local scholars, illegal migrants outnumber legal ones by a ratio of approximately $7: 1$.

The Russian State is trying to control migration, although it lacks experience in so doing because so much of what was "internal migration" two decades ago is today "transnational migration". Migration within Russia is monitored and regulated by the Federal Migration Service, created in 2004 by Decree No. 314 (point 13) of the President of the 
Russian Federation, On the System and Structure of Federal Bodies of Executive Power. The FMS is a federal executive body responsible for implementing State policy in relation to migration, including law enforcement, control, supervision, and the provision of public services. It is currently subordinated to the Government of the Russian Federation (Decree of the President of Russia, May 21, 2012, No. 636). On the first of January 2006 the FMS set up regional branches bringing together passport and visa services and the migration-related subdivisions at the Ministry of the Interior.

One way for migrants from Central Asia to regularize their legal status is by obtaining a so-called "migrant's patent," introduced in 2010. This is a special document confirming the right of foreign nationals who do not require a visa to enter Russia, to remain in the country as employees of a private individual. In this way migrants are legalized in terms of work and taxes, but not in terms of a residence permit. The procedure for obtaining a patent is very simple. They are issued out of the annual quotas for work permits, and are available only to so-called extended visa-free foreigners (i.e., citizens of post-Soviet space). To qualify, the individual must specify the purpose of their travel as employment when filling in migration forms on arrival in Russia. A patent may be extended for a total period of not more than twelve months, after which the individual is expected to leave Russia. In practice, this sometimes means crossing the border and returning after a couple of minutes. It is also theoretically possible, but much more difficult, to obtain a new patent without leaving the country.

Recently the legislative norms of the Russian Federation in regard of the labour migrations undergo a number of changes. The last ammendment regulating the conditions of migrant workers and incorporating changes in the law is adopted at the end of 2014 with Federal Act On the Legal Status of Foreign Citizens in the Russian Federation (Federal'nyı zakon, 2014). An important aspect of these new legislative norms is the official legalization of long-standing practice, as the decree allows employers to take on foreigners temporarily residing in Russia without a work permit. President Vladimir Putin has signed also a law on mandatory of the "migrant's patent" and of Russian language exams for migrants. The system for notifying the Federal Migration Service about foreign employees has also been streamlined, and can now be done electronically. President Putin has also approved changes in existing laws, ensuring migrants' social security and establishing administrative responsibility with regard to their material, health and housing status. This new legislation also tightens responsibility for regularizing illegal migrants.

The general trend in policy towards migrant workers (who mostly originate in the Central Asian countries, and whose labor is needed by the Russian economy) is that migration be promoted, legalized, regulated and controlled. Of particular interest in the region is the official public announcement made by President Putin in December 2012, in which he clearly stated that from 2015 citizens of the Newly Independent States will be required to show international passports (instead of national ID cards, as has been the case since the breakup of the USSR) to cross into the Russian Federation. In compliance with this requirement on 17 $7^{\text {th }}$ June 2014 Decree No. 555 of the Government of the Russian Federation (Postanovlenie, 2014) was adopted and now the citizens of Tajikistan are allowed to enter Russia only with international passports. According to the internal legislation of Uzbekistan any travel of the Uzbek citizens is permitted only for passports holders, thus in practice this requirement also applies to them. As for Kyrgyzstan and Kazakhstan, who are members of the Eurasian Customs Union, their citizens do not need international passports for entering Russian Federation. 
The Russian authorities are making efforts to improve Central Asian migrant workers' conditions for adaptation and integration. Some pilot schemes offering practical courses such as Russian language, introduction to labor law in the Russian Federation, the availability of job opportunities etc. to potential migrants have been set up. They are funded by the "Russian World" foundation, which enjoys special government support and is used to implement various State policies. Some Lyuli living in Tajikistan have heard about these opportunities, and that there are migrants who have obtained employment in Moscow and other Russian cities thanks to special bilateral agreements, but do not benefit from them because they believe that, as Tsygane, these options do not apply to them.

Yet virtually only few Lyuli take advantage of this relatively liberal system. In most cases they do not have the minimum necessary knowledge or social literacy skills to do so. In practice migrant Lyuli continue to rely primarily on established community and regional networks for assistance in employment, housing, obtaining medical services, and - rarely - the education of their children. When talking about such networks informants usually use expressions like "our friends help us," "we have our people," "I get advice from my neighbor," etc.

The main problems of migrant workers from Central Asia in general, and local Lyuli in particular, are associated not so much with the opportunities for labor migration in Russia, but with the situation in their home countries (especially Tajikistan, Uzbekistan and Kyrgyzstan). Most migrate in order to survive and to support their relatives at home. Those who are able to save some money use it to buy (secondhand) cars, repair their homes, or, in some cases, even to build new ones. The difficult economic situation and lack of prospects in Central Asia dooms them to heavy reliance on income earned abroad, i.e. they are bound to migrate to find work, and there are no indications of significant change in this situation, at least for the foreseeable future.

Lyuli, like many people in Central Asia, migrate to escape severe social and economic conditions, and in this sense are part of the region's general migration trends. Lyuli from Uzbekistan and Tajikistan migrate mainly to Russia, but Kazakhstan has recently become a more popular destination, with small numbers even migrating to Kyrgyzstan.

Lyuli face, to some extent, the same problems as other migrants, due to gaps in or even contradictions between local laws concerning migrant workers, and how these are actually implemented by the authorities (e.g. the widespread practice of blackmail by police and migration officers) (Marushiakova \& Popov, 2011). In addition, however, Lyuli experience particular difficulties in integrating into the labor market and social realities of their host countries due to generally low levels of education and poor social literacy coupled with the social stigma associated with their ascribed identity as Tsygane. All these factors contribute to their dependence on informal (often illegal) networks, involvement in begging and other marginal activities, living in unregulated or illegal settlements, and facing increasing hostility and rejection.

Migrant workers from Central Asia are generally labeled "Tajiks," and Lyuli often define themselves as such. The public image of "Tajiks" is deteriorating, and transborder migration is currently one of the most hotly debated issues in the Russian media. Lyuli are also often subject to negative attitudes and stereotypes towards Roma, such as the assumption that they are all involved in drug dealing, or have strong hypnotic powers which they misuse to steal from the majority.

On a positive note, migrant Lyuli in the Russian Federation (and recently also in Kazakhstan) are taking steps towards stabilization, as illustrated by their efforts to gradually 
legalize their status. Such attempts may, however, be periodically hindered by fluctuations in relations between their countries of origin and of residence. The most dramatic instance of this phenomenon, repeatedly mentioned by our informants in Tajikistan and the subject of blanket media coverage at the time, occurred in autumn 2011 when two Russian pilots found guilty of smuggling were given lengthy prison sentences by a Tajik court, and Russia retaliated by expelling large numbers of migrants.

\section{LYULI'S IDENTITY NOWADAYS}

Lyuli migration in the Russian Federation has revealed new dimensions of their identity. As with the Roma worldwide, the identity of Lyuli is multidimensional, hierarchically structured, and - crucially - always contextual, i.e. depending on the social environment, different aspects of identity emerge. In the conditions of Central Asia, the situation is clear and simple: Lyuli are a separate community with their own identity, clearly distinguished from the surrounding population, but sharing a regional consciousness and identification as citizens. On a broader level their Tajik mother tongue determines their preferred Tajik identity in Central Asian countries outside Tajikistan, as well as in Russia.

Developments in preferred ethnic identity for Lyuli outside the Central Asian region can be confirmed by data from censuses of the Russian Federation (which take into account only those who have acquired Russian citizenship). The 2002 census was the first to include, alongside the existing Tsygane ("Gypsies") heading, the separate category of Tsygane Sredneaziatskie ("Central Asian Gypsies"), with other designations (Gurbath, Jughi, Lyuli, Mug'at, Multon, and Tavoktarosh) included as clarification. Significantly, while the 2002 census recorded 486 persons identifying themselves as "Central Asian Gypsies", the next, in 2010, recorded only forty-nine of them (Vserossiǐskaia perepis' naseleniia 2002 goda, n.d.; Vserossiı̌skaia perepis' naseleniia 2010 goda, n.d.). It seems highly unlikely that in the period between the two censuses several hundred "Central Asian Gypsies" who had succeeded in obtaining Russian citizenship (no easy procedure) decided to leave Russia. Much higher is the probability that they declared another identity in the second census.

In the course of their migrations within the Russian Federation, Lyuli come into increased contact with European Roma and with local preconceptions concerning them. They are therefore compelled to seek ways of differentiating themselves from these other Tsygane. When the researchers asked Lyuli in Moscow about their ethnicity, they all insisted at first that they were Tajik (regardless of country of origin). Only in response to repeated requests for clarification did they say, "We are Mug'at," in conjunction with which many emphasized repeatedly "Mug'at, that's a kind of Tajik," i.e. they tried to present Mug'at as an internal division of Tajiks. When asked if they could be considered Tsygane, the answer was "We are not like them." The Lyuli label was rejected too, out of fear that it could be seen as coming under the Tsygane or "Gypsies" heading. Yet at home in Central Asia, where they are not being compared with Tsygane in the Russian Federation, they describe themselves as Tsygane when speaking Russian. Only in some places in Central Asia, in rare cases of outright conflict with European Tsygane, do Lyuli refuse to apply the Russian term to themselves. As for the appellation "Roma", which has in recent decades been adopted throughout Europe as the politically correct umbrella term for 
various communities, it is generally completely unknown, and incomprehensible, to Lyuli. The dividing line between Lyuli and Roma is kept also because the mutual rejection. Attitudes of local Roma in Russia towards migrating Lyuli are generally negative, and they strongly distinguish themselves from them, as well as from Hungarian-speaking Madyari (from Transcarpathia). To the Roma way of thinking, Lyuli cannot be considered to be nastoyashchie Tsygane ("real Gypsies") partly because they are poor and live by begging and, even more crucially, do not speak Romanes and are Muslims.

International institutions and NGOs (mostly those acting in the field of human rights), by contrast, in past have not generally distinguished between Lyuli and Roma. In recent years there is some recognition that these are different kinds of communities (European Roma Right Centre, 2005; ADTs Memorial, 2010), but still some authors continue to consider Lyuli to be inseparable part of the Gypsies, equating this term with notion of Roma (Bessonov, 2000, 2003; Günter, 2007, 2011), however these factors are insufficient to influence significant changes in the identity of Lyuli.

CONCLUSIONS

The Lyuli and other similar Central Asian groups continue to face social exclusion and discrimination, and in this their experience is similar to that of European Roma: their status and position have deteriorated since independence. In the USSR they were just one, very small entity among hundreds of different "nationalities" in a multinational State and were able to profit from mainstream policies implemented. In the newly independent nation-states they have become more visible, and more easily singled out. Deteriorating provision in health and education, high unemployment, corruption, administrative arbitrariness, lack of social security, etc., endemic in most of the region's countries, impact with particular severity on local "Gypsies." Under these circumstances manifestations of intolerance and discrimination against $L y u l i$ and other similar groups encounter no serious resistance from the relevant institutions of new and fragile nation-states.

The condition of Central Asian Lyuli in the individual countries of their home region displays common social and economic problems, but different levels of social disengagement of their communities from their respective ethnic majorities. In Kyrgyzstan, they are perceived as alien, not belonging to the "land of the Kyrgyz," whereas in Tajikistan they are considered to be part of the country landscape, thus also part of the Tajik nation. The difficult social and economic situation of Lyuli in their countries of origin, and the absence of prospects for development at home, compels them to rely primarily on income earned abroad. Thus they are doomed to be migrant workers, and there are no indications of significant improvement for the foreseeable future. On the contrary, all available data show a trend of increasing migration combined with continuing integration difficulties in host countries, where their needs and rights are ignored or neglected by the relevant institutions. Nowadays the problems of the so-called Central Asian 'Gypsies', including the Lyuli, can not (and should not) be considered only in the context of particular countries in Central Asia whose citizens they are. It is more revealing to analyze them in the context of current realities in post-Soviet space as a whole, both the Russian Federation and the Newly Independent States, which remain linked to it in myriad ways. In spite of globalization of processes of identity formation and nation building among Roma in Europe and 
continuation of linking Lyuli with Roma however we can not expect to see former leaving the post-soviet context and entering common policy space with European Roma.

\section{REFERENCES}

Abashin, S. (2004). Sredneaziatskaia bogema. Retrieved January 25, 2014, from http:// www.sakharov-center.ru/museum/exhibitionhall/prishelci/hall_exhibitions_current_prishelci.htm.

Abashin, S. (2007). Natsionalizmy v Srednei Azii: V poiskakh identichnosti. St. Petersburg: Aleteйia.

ADTs Memorial (Anti-Discrimination Center Memorial). (2010). Diskriminatsiia ètnicheskikh men'shinstv i migrantov $v$ realizatsii sotsial'no-ékonomicheskikh i kul'turnykh prav v Rossii. St. Petersburg: ADTs Memorial.

ADTs Memorial. (2005). Violation of the rights of Roma children. Retrieved January 25, 2015, from https://www.fidh.org/International-Federation-for-Human-Rights/easterneurope-central-asia/russia/Violation-of-the-rights-of-Roma.

Bessonov, N. V. (2000). Tsygane i pressa (Issue 1). Moscow. (No publisher)

Bessonov, N. V. (2003). Tsygane i pressa (Issue 2). Moscow. (No publisher)

Bessonov, N. V. (2008). Sredneaziatskie tsygane i ikh kochev'e po Rossii. Ėtnopanorama, (3-4), 27-39.

Bol'shaia Sovetskaia Ėntsiklopediia (BSE). (1970-1978). (3th ed.). Moskva: Gosudarstvennoe Nauchnoe Izdatel'stvo BSE. Retrieved January 25, 2015, from http://dic.academic. ru/dic.nsf/bse/133856/\% D0\%A1\%D0\%BE\%D0\%B2\%D0\%B5\%D1\% 82\%D1\% 81\% D0\%BA\%D0\%B8\%D0\%B9.

CAHROM (2015) 16. AD HOC COMMITTEE OF EXPERTS ON ROMA ISSUES ICAHROM). 9 CAHROM MEETING. Strasbourg, 27-29 May 2015. Retrieved January 25, 2015, from https://rm.coe.int/CoERMPublicCommonSearchServices/DisplayDCTMCon tent?documentld=09000016803061e5.

Crowe, D. (1993). The Liuli (Gypsies) of Central Asia. Bulletin of the Association for the Advancement of Central Asian Research, 6(1), 2-6.

Declaration of the Committee of Ministers on the Rise of Anti-Gypsyism and Racist Violence against Roma in Europe. (2012). Adopted on 1 February 2012. Retrieved April 14, 2015. https://wcd.coe.int/ViewDoc.jsp?id=1902151.

Demeter, N. G. (1980). Ėtnonimy sredneaziatskikh tsygan. In Onomastika Sredner Azii (pp. 143-149). Frunze: Izd-vo "Ilim".

Demeter, N. G., Bessonov, N. V., \& Kutenkov, V. K. (2000). Istoriia tsygan: Novyı vzgliad. Voronezh: Institut ètnologii i antropologii RAN.

Ėkspert: V tsentre Kazani liuli zakhvatili tsely̆ kvartal. (2012, June 19). Natsional'ny̆ aktsent: Media-proekt Gil'dii mezhètnicheskor zhurnalistiki. Retrieved January 25, 2015, from http://nazaccent.ru/content/4771-ekspert-v-centre-kazani-lyuli.html.

European Commission. 2011. EU Framework for National Roma Strategies up to 2020. Retrieved July 25, 2015, from http://ec.europa.eu/justice/policies/discrimination/docs/ com_2011_173_en.pdf. 
European Commission. 2012. National Roma Integration Strategies: A first step in the implementation of the EU Framework. Retrieved July 25, 2015, from http://ec.europa.eu/ justice/discrimination/files/com2012_226_en.pdf.

European Roma Right Centre (ERRC). (2005). In search of happy Gypsies: Persecution of pariah minorities in Russia. Budapest: European Roma Right Centre. (Country Report Series, 14)

Federal'ny̆ zakon ot 24.11.2014 № 357-FZ “O vensenii izmenenii v Federal'ny̆ zakon "O pravovom polozhenii inostrannykh grazhdan $\vee$ Rossiiskoı̆ Federatsii" i otdel'nye zakonodatel'nye akty Rossiskoĭ Federatsii". http://publication.pravo.gov.ru/Document/ View/0001201411250019

Gabbasov, S. M. (2008a). Problematika samonazvaniia i samoopredeleniia u sredneaziatskikh "mugat". Retrieved January 25, 2014, from http://centr-asia.narod.ru/problem. htm.

Gabbasov, S. M. (2008b). Tsyganoobraznye gruppy Gissarskoĭ doliny (po materialam issledovaniĭ I. M. Oranskogo). Retrieved January 25, 2014, from http://centr-asia.narod.ru/gissar_vall.htm.

Gabbasov, S. M., \& Cherenkov, L. N. (2008). Tsygane Blizhnego Vostoka i Tsentral'noı̆ Azii. Retrieved January 25, 2014, from http://centr-asia.narod.ru/mideast.htm.

Günther, O. (2007). Laissez faire und totale Erfassung: Die staatliche Verwaltung zigeunerischer Gruppen in Mittelasien. Orientwissenschaftliche Hefte, (25), 103-120.

Günther, O. (2011). Zigeunerkulturen im städtischen Zwischenraum. In M. Jessat \& O. Günther (Eds.), Oase, Zelt und Zwischenraum: 3 mal Afghanistan (pp. 86-98). Altenburg: Mauritianum.

K nam priekhal tabor. (2010, July 6). Retrieved January 25, 2015, from http://zemliaki.info/ publ/2010_god/5_2010_god/k_nam_priekhal_tabor/12-1-0-110.

Khakimov, N. (2010, July 6). Mugaty - skital'tsy v poiskakh schast'ia. Khudzhand: Nauchno-issledovatel'skir institut iskusstvovedeniia g. Khudzhand.

Marszewski, M. (2011). Cyganie środkowoazjatyccy - ofiary rozpadu Związku Radzieckiego. Retrieved January 25, 2015, from http://www.etnologia.pl/swiat/teksty/cyganiesrodkowoazjatyccy-2.php.

Marushiakova, E., \& Popov, V. (2003). Ethnic identities and economic strategies of the Gypsies in the countries of the former USSR. Orientwissenschaftliche Hefte (9) 289310.

Marushiakova, E., \& Popov, V. (2008). State policies under communism. In Fact Sheets on Roma History. Strasbourg: Council of Europe. Retrieved January 25, 2015, from http://www.coe.int/t/dg4/education/roma/histoCulture_en.asp.

Marushiakova, E., \& Popov, V. (2011). Migratsii tsygan iz Sredneì Azii v Rossiiu. In Migratsionnyı̆ most mezhdu Tsentral'nŏ Azier̆ i Rossier̆: Rol' migratsii v modernizatsii i innovatsionnom razvitii ékonomiki stran, posylaiushchikh i prinimaiushchikh migrantov (pp. 352-356). Moscow: Ekon-inform.

Muzhchiny iz tsyganskogo tabora pytaiutsia naìti rabotu $\vee$ Yuzhno-Sakhalinske. (2008, May 7). Nashi ostrova: Obshchestvenno-politicheskaia gazeta. Retrieved January 25, 2015, from http://www.tia-ostrova.ru/?div=news\&id=107403.

Na Sakhalin na zarobotki vpervye pribyla gruppa tsygan iz blizhnego zarubezh'ia. (2008, May 8). Sakhalin - Kuryli: Informatsionnoe agentstvo. Retrieved January 25, 2015, from http://www.skr.su/news/189470. 
Nazarov, K. K. (1968a). K voprosu o korennykh preobrazovaniiakh kul'tury i byta sredneaziatskikh tsygan $\vee$ period postroeniia sotsializma v SSSR. Nauchnye trudy Samarkandskogo meditsinskogo instituta, (43), 67-73.

Nazarov, K. K. (1968b). Razlichnye gruppy sredneaziatskikh tsygan. In Materialy respublikanskoĭ nauchno-teoreticheskor konferentsii molodykh uchenykh i aspirantov (pp. 43-45). Samarkand.

Nazarov, K. K. (1968c). Razvitie gruppy sredneaziatskikh tsygan. In Materialy respublikanskor nauchno-prakticheskoĭ konferentsii molodykh uchenykh i aspirantov (pp. 53-55). Samarkand.

Nazarov, K. K. (1969a). Priobshchenie sredneaziatskikh tsygan k trudovor deiatel'nosti plod sotsialisticheskoř revoliutsii. In Tezisy dokladov 50-ǐ nauchnoĭ konferentsii kafedr obshchestvennykh nauk (pp. 73-77). Samarkand.

Nazarov, K. K. (1969b). Sotsial'nye otnosheniia u liuli (tsygan) $\vee$ dorevoliutsionnom proshlom. In Tezisy dokladov 50-̌ nauchnoi konferentsii kafedr obshchestvennykh nauk (pp. 68-72). Samarkand.

Nazarov, K. K. (1970). Vliianie Oktiabr'skoĭ revoliutsii na polozhenie i byt sredneaziatskikh tsygan. Avtoreferat. Moskva.

Nazarov, K. K. (1975). Different groups of middle-Asian Gypsies. Roma, 1(3), 3-23.

Nazarov, K. K. (1980). Sovremennoe ètnicheskoe razvitie sredneaziatskikh tsygan (liuli). In R. Dzharilgasinova \& L. Tolstova (Eds.), Ėtnicheskie protsessy u natsional'nykh grupp Srednei Azii i Kazakhstana (pp. 165-185). Moskva.

Nazarov, K. K. (1982). Contemporary ethnic development of the Central Asian Gypsies (Lyuli). Anthropology \& Archeology of Eurasia, 21(3), 3-28. Retrieved January 25, 2015, from http://doi.org/10.2753/AAE1061-195921033.

Nelegal'nyı̆ tsyganskiĭ tabor byl obnaruzhen pod Novosibirskom. (2012, July 20). Natsional'ny̆ aktsent: Media-proekt Gil'dii mezhetnicheskoy zhurnalistiki. Retrieved January 25, 2015, from http://nazaccent.ru/content/5026-eshe-odin-cyganskij-tabor-bylobnaruzhen.html.

Neprikayannye. (24.11.1997). - Vechernĭ Minsk, Nr. 224 (8782). Retrieved January 25, 2014, from http://www.belarus.net/minsk_ev/97/russia/no7/neprik24.htm.

Oransky, I. M. (1956a). Indoiazychnaia ètnograficheskaia gruppa "afgon" v Sredneì Azii. Sovetskaia ètnografiia, (2), 17-124.

Oransky, I. M. (1956b). Predvaritel'noe soobshchenie ob obnaruzhennom v Sredneı̆ Azii indiüskom dialekte. Sovetskoe vostokovedenie, (4), 144-151.

Oransky, I. M. (1960a). Ob obnaruzhennom v Sredner Azii indǐskom dialekte. Moskva: Institut vostochnoı̆ literatury.

Oransky, I. M. (1960b). On an Indian dialect discovered in Central Asia. In Trudy Dvadtsat' piatogo mezhdunarodnogo kongressa vostokovedov. Moskva, 9-16 avgusta $1960 \mathrm{~g}$. (Vol. 4, pp. 30-37). Moskva: Institut vostochnoĭ literatury.

Oransky, I. M. (1961). Novye svedeniia o sekretnykh iazykakh (argo) Sredneĭ Azii. Ėtnograficheskaia gruppa "kavol" v Kuliabe i ee argo. In Kratkie soobshcheniia instituta narodov Azii, 40: Yaazykoznanie, 62-77.

Oransky, I. M. (1963). Indǐskil dialekt gruppy par'ia (Gissarskaia dolina). Materialy i issledovania (Pt. 1: Teksty (fol'klor)). Moskva: Nauka.

Oransky, I. M. (1964a). Dva indoariiskikh dialekta iz Sredneĭ Azii. In Indo-iranskaia filologiia (pp. 3-16). Moskva: Nauka. 
Oransky, I. M. (1964b). Novye svedeniia o sekretnykh iazykakh (argo) Sredneı̆ Azii: II. Materialy dlia izucheniia argo ètnograficheskoľ gruppy "dzhugi" (Gissarskaia dolina). In Iranskaia filologiia: Trudy nauchnoŭ konferentsii po iranskoĭ filologii (24-27 Febr. 1962) (pp. 62-75). Leningrad.

Oransky, I. M. (1967). Indo-iranskie dialekty Gissarskoĭ doliny: Materialy i issledovaniia. Avtoreferat. Leningrad: LGU.

Oransky, I. M. (1971a). Novye svedeniia o sekretnykh yazykakh (argo) Sredneĭ Azii: III. Ėtnograficheskaya gruppa chistoni, ee dialekt i argo. In N. A. Dvoriankov (Ed.), Indǐskaia i iranskaia filologiia: Voprosy dialektologii (pp. 66-99). Moskva: Nauka.

Oransky, I. M. (1971b). O termine "mazang" v Sredner Azii. Strany i narody Vostoka, 10, 202-207.

Oransky, I. M. (1977). Fol'klor i iazyk gissarskikh par'ia (Sredniaia Aziia). Vvedenie, teksty, slovar'. Moskva: Nauka.

Oransky, I. M. (1983). Tadzhikoiazychnye ètnograficheskie gruppy Gissarskol doliny (Sredniaia Aziia). Moskva: Nauka.

Perepisi naseleniia Rossiľskoĭ Imperii, SSSR, 15 novykh nezavisimykh gosudarstv. (2012). Demoskop Weekly, pp. 535-536. Retrieved January 25, 2015, from http://demoscope. $\mathrm{ru} /$ weekly/ssp/census.php?cy=7.

Polnoe sobranie zakonodatel'stva SSSR: Sistema dostupa k baze vsekh normativno-pravovykh aktov Soiuza Sovetskikh Sotsialisticheskikh respublik. (n.d.). Retrieved January 25, 2015, from www.ussrdoc.com.

Postanovlenie Pravitel'stva RF ot 17 iynya 2014 g. N 555 “O priznanii utrativshim silu postanovleniya Pravitel'stva Rossiiskoǐ Federatsii ot 21 sentyabrya 2005 g. N 574". http:// base.garant.ru/70680422/.

Report of the Special Rapporteur on minority issues, Rita Izsák. United Nations. General Assembly. Human Rights Council. Twenty-ninth session. Agenda item 3: Promotion and protection of all human rights, civil, political, economic, social and cultural rights, including the right to development. 11 May 2015. Retrieved July 25, 2015, from http://www.ohchr.org/EN/HRBodies/HRC/RegularSessions/Session28/Documents/A_ HRC_28_64_Add_2_SPA.doc.

Russia and Tajikistan: Pilots sentenced and migrants deported. (2011, November 21). Retrieved January 25, 2015, from http://globalvoicesonline.org/2011/11/21/russia-andtajikistan-pilots-sentenced-and-migrants-deported/.

Shkurenok, N. (2009, September). Doma tadzhikskikh tsygan sozhgli v Gorelovo. Biulleten' ADTs Memorial, (27). Retrieved January 25, 2015, from http://adcmemorial.org/ www/263.html.

Skakirov D. (2010, April 21). A chto naĭdut - tem i zhivut. Media Zavod. Retrieved January 25, 2015, from http://aloepole.ru/articles/1198906979/a-1271911373.

Snesarev, G. P. (1960). Sredneaziatskie tsygane. Kratkie soobshcheniia Instituta ètnografii AN SSSR, 34, 24-29.

Snesarev, G. P., \& Troitskaia, A. L. (1963). Sredneaziatskie tsygane. In Narody Srednĕ Azii i Kazakhstana (Vol. 2, pp. 597-609). Moskva.

Surgut "zachistili" ot uzbekskikh tsygan. (2002, July 19). Informatsionnoe agentstvo Tiumenskaia liniia. Retrieved January 25, 2015, from http://www.t-l.ru/22063.html.

Tul'sky, M. (2005). Itogi perepisi naseleniya Tadzhikistana 2000 goda: natsional'nyi, vozrastnoi, polovoi, semeinyi i obrazovatel'nyi sostavy. [Results of the People Census in 
Tajikistan in 2000: National, Age, Gender, Family and Educational Composition] - Demoskop Weekly 191-192. http://demoscope.ru/weekly/2005/0191/analit05.php.

$\checkmark$ Berdske obnaruzhili liuli. (2012, April 20). Natsional'ny̆ aktsent: Media-proekt Gil'dii mezhètnicheskoĭ zhurnalistiki. Retrieved January 25, 2015, from http://nazaccent.ru/ content/4353-v-berdske-obnaruzhili-lyuli.html.

Vremia lyuli: Tadzhikskie tsygane izvlekaiut pol'zu iz nesovershenstva rossiǐskikh zakonov. (2003, May 22). Molodezh' Severa: Ezhenedel'naia obshchestvenno-politicheskaia gazeta Respubliki Komi. Retrieved January 25, 2015, from http://www.mskomi.ru/arhiv/ new055.htm.

Vserossiǐskaia perepis' naselenia 2002 goda. (n.d.). Retrieved January 25, 2015, from http://www.perepis2002.ru/index.html?id=17.

Vserossiǐskaia perepis' naselenia 2010 goda. (n.d.). Retrieved January 25, 2015, from http://www.gks.ru/free_doc/new_site/perepis2010/croc/perepis_itogi1612.htm.

Walker, S. (2011, November 19). Tajikistan says it may release Russian pilot. Retrieved January 25, 2015, from http://www.independent.co.uk/news/world/europe/tajikistansays-it-may-release-russian-pilot-6264624.html.

This work was supported by the authors' own resources. No competing interests have been declared.

Both authors participated in elaborating research ideas and writing the manuscript_. 